\title{
These Untitled Little Verses in Which, At Dawn, Two Obscure Dutch Peasants Struggled with an Auburn Horse / Norman Dubie
}

The water is green. The two boats out at a distance Are silver, and the two gulls coming in

Off the water are, also, silver;

But these peasants and their horse, at first light,

Seem absorbed in the pitch-blackness Of a previous night. They are in a field

That climbs away from the sea joining A thick row of white almond trees.

The younger of the two men holds a small branch, The other

Holds a rope that leads away from the horse Running over his shoulder and underneath the arm

To a pool of rope beneath him: he leans,

Or he reclines like a lever in the scene.

The auburn horse

Represents some inevitable sadness

That will visit each of us, that visits

These two peasants struggling in a winter pasture.

It is the morning.

It is dawn. These three may

Signal a common enough passage from the night To the day. It begins like pain for the older man:

It begins to rain.

The two men run to the trees just above them 
And the horse, ignorant of everything, walks away

Like a skilled butcher from a dark, maimed

Lamb still wiggling in the grass behind him. And Morning surrenders to mid-day, and the afternoon

To the evening, and the evening surrenders everything

To the sleep of these two peasants

Who have had a discouraging day in the fields:

They dream of the black, burial horses of a king

With heavy sable plumes and the blinders

Of gold-leaf made starry with diamonds,

Horses not like the auburn mare who stood

In a world that

Belongs to a system of things

Which presents a dark humus with everything

Living: all of us preceded

Not by the lovely, braided horses

Of which the peasants dreamed, but by these two

Peasants and their horse struggling

Briefly, at dawn, in the deep trenches

Of a field beside the green, winter sea!

\section{Premonition / Mark Jarman}

Mother, I see you blocking the door, your skin is a mesh of light

letting the night through, your breasts are no longer toylike as in the bath, they are cones of moonlight tipped with darkness, 